\title{
Pengaruh Religiusitas, Sikap, Norma Subjektif, dan Kontrol Perilaku terhadap Niat Membeli Produk Kosmetik Halal di Fakultas Ekonomi dan Bisnis Universitas Ahmad Dahlan Yogyakarta
}

\author{
Reza Rizki Nur Ikhsan ${ }^{1)}$, Sukardi ${ }^{2)}$ \\ 1), 2) Program Studi Magister Manajemen, Universitas Ahmad Dahlan \\ Jl. Pramuka No. 42, Pandeyan, Umbulharjo, Yogyakarta 55161 \\ Email: rezarizki376@gmail.com ${ }^{l}$
}

\begin{abstract}
This study aims to determine the effect of religiosity, attitudes, subjective norms and behavioral control on the intention to buy halal cosmetic products on Muslim students at the Faculty of Economics and Business, Ahmad Dahlan University, Yogyakarta. This research is a survey research using a questionnaire as an instrument. For testing the instrument using a test of validity and reliability. As for the technique of data analysis using multiple linear regression methods, because the variables used are more than two variables, with the F test and t test. The results of the study showed that the religiosity variable (XI) did not significantly influence the intention to buy halal cosmetics, this was indicated by the significance value $>\alpha(0.24)>0.05)$ attitude $(X 2)$ had no significant effect on the intention to buy halal cosmetics, this is shown from the significance value $>\alpha(0.509>0.05)$, subjective norm $(X 3)$ does not affect the intention to buy halal cosmetics, this is indicated from the significance value $>\alpha(0,250>0.05)$, behavioral control (X4) influences on the interest in buying halal cosmetics, this is indicated by the significance value $<\alpha(0,000<0.05)$. Simultaneously the influence of religiosity, attitudes, subjective norms, and behavioral control on the intention to buy halal cosmetic products at the Faculty of Economics and Business Ahmad Dahlan University has a significant effect on the intention to buy halal cosmetics (Y). This is evidenced by the calculation of the $F$ test of 28,135 with a significance of 0,000 .
\end{abstract}

Keywords: Religiosity, Attitude, Intention, Halal Cosmetics

\begin{abstract}
ABSTRAK
Penelitian ini bertujuan untuk mengetahui pengaruh religiusitas, sikap, norma subyektif dan kontrol perilaku terhadap niat membeli produk kosmetik halal pada mahasiswi muslim di Fakultas Ekonomi dan Bisnis Universitas Ahmad Dahlan Yogyakarta. Penelitian ini merupakan penelitian survei dengan menggunakan kuesioner sebagai instrumennya. Untuk pengujian instrumen menggunakan uji validitas dan reliabilitas. Sedangkan untuk Teknik analisis data menggunakan metode regresi linier berganda, karena variabel yang digunakan lebih dari dua variabel, dengan uji $\mathrm{F}$ dan uji t. Hasil dari penelitian menunjukkan bahwa variabel religiusitas $\left(\mathrm{X}_{1}\right)$ tidak berpengaruh signifikan terhadap minat beli kosmetik halal, hal ini ditunjukkan dari nilai signifikansi $>\alpha(0,24>0,05)$ sikap $\left(\mathrm{X}_{2}\right)$ tidak berpengaruh signifikan terhadap minat beli kosmetik halal, hal ini ditunjukkan dari nilai signifikansi $>\alpha(0,509>0,05)$, norma subjektif $\left(\mathrm{X}_{3}\right)$ tidak berpengaruh terhadap minat beli kosmetik halal, hal ini ditunjukkan dari nilai signifikansi $>\alpha(0,250)>0,05)$, kontrol perilaku $\left(\mathrm{X}_{4}\right)$ berpengaruh terhadap minat beli kosmetik halal, hal ini ditunjukkan dari nilai signifikansi $<\alpha(0,000<0,05)$. Secara simultan pengaruh religiusitas, sikap, norma subjektif, dan kontrol perilaku terhadap niat membeli produk kosmetik halal di Fakultas Ekonomi dan Bisnis Universitas Ahmad Dahlan berpengaruh signifikan terhadap niat membeli kosmetik halal (Y). Hal ini terbukti dengan perhitungan uji F sebesar 28,135 dengan signifikansi 0,000.
\end{abstract}

Kata Kunci: Religiusitas, Sikap, Niat, Kosmetik Halal

\section{Pendahuluan}

Kegiatan konsumsi merupakan sebuah kegiatan yang tidak bisa terlepas dari kehidupan manusia. Manusia membutuhkan makanan dan minuman untuk bertahan hidup, manusia membutuhkan pakaian untuk menutupi tubuhnya, dan manusia membutuhkan obatobatan ketika jatuh sakit. Kebutuhan manusia merupakan suatu kondisi akan sebagian dari pemuasan dasar atau yang disadari. Seperti halnya dengan kosmetik, kosmetik hadir dengan tujuan untuk memenuhi kebutuhan mendasar bagi wanita akan kecantikan. Pada era sekarang ini, kosmetik sudah menjadi kebutuhan yang tidak hanya dibutuhkan oleh kaum wanita saja, akan tetapi kaum laki-laki juga sudah banyak yang menggunakan produk kosmetik sebagai bagian dari kebutuhan, bukan sebagai kecantikan, akan tetapi lebih kepada perawatan kesehatan.

Kesadaran masyarakat tentang tingkat keamanan kosmetika yang digunakan sudah semakin meningkat seiring dengan munculnya berbagai macam kasus dari dampak berbahayanya dalam kosmetik. Akan tetapi, kesadaran masyarakat muslim untuk memperhatikan kehalalan kosmetik tersebut masih rendah. Produk kosmetik memang tidak dimakan dan tidak masuk ke dalam tubuh. Oleh karena itu produk kosmetik dikaitkan dengan masalah suci atau najis. Badan atau kulit kita 
menjadi najis apabila menggunakan kosmetik yang mengandung bahan-bahan haram. Bahan-bahan haram atau najis tersebut seperti sodium heparin yang berasal dari hewan babi yang ditemukan pada beberapa produk krim nutrisi kulit dan krim anti jerawat.

Dalam memilih produk yang akan dibeli, Shiffman dan Kanuk (2008) mengemukakan ada beberapa faktor yang mempengaruhinya seperti psikologi konsumen (meliputi motivasi, persepsi, kepribadian, dan sikap), lingkungan sosial budaya (meliputi keluarga, kelas sosial, dan sub-budaya), dan paduan dari bauran pemasaran. Agama merupakan salah satu dari subbudaya yang berarti perintah atau larangan dalam agama dapat mempengaruhi keputusan seseorang dalam membeli sesuatu. Seorang individu seharusnya tidak memilih produk yang akan dikonsumsi dengan hanya melihat kebutuhannya saja, melainkan harus relevan dengan aturan-aturan agama dan keyakinan yang dianutnya (Minkler and Cosgel, 2004). Oleh karena itu, tingkat ke religiusitasan seseorang dalam memilih produk yang halal seperti kosmetik, juga sangat menentukan, apakah niat orang tersebut memilih produk kosmetik halal karena orang tersebut mengamalkan ajaran agama dan memahami ilmu-ilmu agama untuk mengkonsumsi yang halal, atau karena sekedar memilih produk kosmetik halal karena terdapat label halal pada produk tersebut.

Menurut Nasrullah (2015) yang mengutip dari pendapat Dellener yang menyatakan bahwa religiusitas adalah salah satu faktor pendorong penting dan dapat berpengaruh terhadap perilaku konsumen. Hal ini didasari atas keputusan konsumen untuk membeli produk tergantung kadar keimanan mereka. Religiusitas seseorang bisa dikenali dengan beberapa ritual yang dilakukan oleh seorang, seperti beribadah sholat lima waktu, membaca Al-Qur'an, zakat, sedekah, berpuasa, serta makanan yang dimakan, dan lain-lain. Terkait dengan perilaku konsumsi dimana agama merupakan salah satu sub-budaya yang mempengaruhi perilaku konsumsi seorang individu, pilihan atas produk yang akan dikonsumsi membantu untuk mengenali dan menyampaikan religiusitas seseorang.

Dalam penelitian ini penulis merumuskan masalah sebagai berikut:

1. Apakah religiusitas seseorang berpengaruh terhadap niat membeli produk kosmetik halal?

2. Apakah sikap berpengaruh terhadap niat membeli produk kosmetik halal?

3. Apakah norma subjektif berpengaruh terhadap niat membeli produk kosmetik halal?

4. Apakah kontrol perilaku berpengaruh terhadap niat membeli produk kosmetik halal?

5. Apakah religiusitas, sikap, norma subjektif, dan kontrol perilaku berpengaruh terhadap niat membeli produk kosmetik halal?

\section{Metode Penelitian}

\subsection{Populasi dan Sampel}

Populasi adalah wilayah generalisasi yang terdiri atas objek atau subjek yang mempunyai kualitas dan karakteristik tertentu yang ditetapkan oleh peneliti untuk dipelajari dan kemudian ditarik kesimpulannya (Sugiyono, 2015). Populasi pada penelitian ini adalah seluruh staf karyawan, dosen dan mahasiswa/mahasiswi di Fakultas Ekonomi dan Bisnis Universitas Ahmad Dahlan Yogyakarta.

Sampel adalah bagian dari jumlah dan karakteristik yang dimiliki oleh populasi tersebut (Sugiyono, 2015:118). Sampel yang digunakan dalam penelitian ini adalah mahasiswi yang beragama muslim yang berada di Fakultas Ekonomi dan Bisnis Universitas Ahmad Dahlan Yogyakarta.

\subsection{Teknik Pengambilan Sampel}

Teknik sampling adalah teknik pengambilan sampel. Teknik pengambilan sampling yang digunakan adalah purposive sampling yaitu teknik pengambilan sampel sumber data dengan pertimbangan tertentu (Sugiyono, 2015:300). Pertimbangan tertentu ini, adalah misallnya orang tersebut yang dianggap paling tahu tentang apa yang kita harapkan, atau mungkin dia sebagai penguasa sehingga akan memudahkan peneliti menjelajahi objek/situasi sosial yang diteliti.

\subsection{Jenis Data dan Sumber Data}

Dalam penelitian ini, data yang digunakan yaitu data primer, yaitu dengan memberikan data secara langsung kepada pengumpul data dengan menggunakan kuesioner. Data tersebut berupa persepsi responden dari variabel yang ada.

\subsection{Teknik Pengumpulan Data}

Untuk memperoleh data dan informasi yang akurat dalam penelitian ini, maka diperlukan teknik pengumpulan data yang baik dan terencana. Teknik pengumpulan data dalam penelitian ini yaitu menggunakan kuesioner atau angket. Kuesioner adalah teknik pengumpulan data yang dilakukan dengan cara memberi seperangkat pertanyaan atau pernyataan tertulis kepada responden untuk dijawabnya (Sugiyono, 2015).

Kusioner atau angket yang digunakan dalam penelitian ini adalah angket tertutup dimana pernyataan disajikan dalam bentuk yang terstruktur sehingga responden hanya diminta untuk memilih salah satu jawaban yang sesuai dengan karakteristik dirinya. Kusioner yang akan disebar kepada responden berisi pernyataan-pernyataan tertulis yang akan dijawab oleh responden yang berhubungan dengan pengaruh religiusitas, sikap, norma subjektif, kontrol perilaku terhadap niat beli produk kosmetik halal.

\subsection{Pengukuran Variabel}

Alat ukur variabel skala pengukuran yang digunakan adalah skala likert dengan lima alternatif jawaban. Skala likert digunakan untuk mengukur sikap, pendapat, dan persepsi seseorang atau sekelompok orang tentang fenomena sosial dalam suatu penelitian (Sugiyono, 2015). Angka 1 menunjukkan bahwa responden sangat tidak setuju terhadap pernyataan yang diberikan, dan 
sedangkan angka 5 menunjukkan bahwa responden sangat setuju terhaap pernyataan yang telah diberikan.

\subsection{Uji Instrumen Penelitian Uji Validitas}

Validitas menunjukan sejauh mana suatu pengukur itu mengukur apa yang ingin diukur. Hasil penelitian yang valid terjadi apabila terdapat kesamaan antara data yang terkumpul dengan data yang sesungguhnya terjadi pada objek yang diteliti. Validitas berarti instrumen yang dipilih dapat digunakan untuk mengukur apa yang seharusnya diukur ( Sugiyono, 2015).

\section{Uji Reliabilitas}

Reliabilitas menunjukkan konsistensi dan stabilitas dari suatu skor (skala pengukuran). Hasil pengukuran dapat dipercaya bila dalam beberapa kali pelaksanaan pengukuran terhadap kelompok subyek yang sama diperoleh hasil yang relatif sama, selama aspek yang diukur tidak berubah. Uji reliabilitas pada penelitian ini menggunakan metode Cronbach Alpha untuk menentukan apakah setiap instrumen reliabel atau tidak. Pengukuran ini menggunakan uji statistik Cronbach Alpha.

\subsection{Teknik Analisis Data}

Analisis Regresi Linear Berganda

Analisis regresi digunakan untuk mengetahui besarnya pengaruh variabel independen (religiusitas, sikap, norma subjektif, dan kontrol perilaku) terhadap variabel dependen (niat). Persamaan regresi linier berganda secara umum dapat dijelaskan sebagai berikut:

$$
\mathbf{Y}=\mathbf{a}+\mathbf{b}_{1} \mathbf{X}_{1}+\mathbf{b}_{2} \mathbf{X}_{2}+\mathbf{b}_{3} \mathbf{X}_{3}+\mathbf{b}_{4} \mathbf{X}_{4}+\mathbf{e}
$$

\section{Uji Signifikan Parsial (Uji t)}

Uji t digunakan untuk mengetahui pengaruh dari masing-masing variabel bebas secara parsial terhadap variabel terikat. Untuk mengetahui apakah ada pengaruh secara parsial variabel bebas terhadap variabel terikat. Dapat juga dikatakan $\mathrm{H}_{\mathrm{o}}$ diterima jika $\mathrm{t}_{\text {hitung }}<\mathrm{t}_{\text {tabel }}$ dengan $\alpha=5 \%$ dan signifikansi t hitung lebih besar dari 0,05 dan $\mathrm{H}_{\mathrm{a}}$ diterima jika $\mathrm{t}_{\text {hitung }}>\mathrm{t}_{\text {tabel }}$ dengan $\alpha=5 \%$ dan signifikansi thitung lebih kecil dari 0,05.

\section{Uji Signifikan Simultan (Uji F)}

Uji $F$ atau pengujian model digunakan untuk mengetahui pengaruh secara simultan antara variabel bebas terhadap variabel terikat. Untuk mengetahui apakah model regresi linier berganda yang digunakan sesuai atau tidak. $\mathrm{H}_{\mathrm{o}}$ diterima jika $\mathrm{F}_{\text {hitung }}<\mathrm{F}_{\text {tabel }}$ dengan $\alpha=5 \%$ dan signifikansi $\mathrm{F}$ hitung lebih besar dari 0,05 dan $\mathrm{H}_{\mathrm{a}}$ diterima jika $F_{\text {hitung }}>F_{\text {tabel }}$ dengan $\alpha=5 \%$ dan signifikansi $F$ hitung lebih kecil dari 0,05.

\section{Pembahasan}

\subsection{Statistik Deskriptif}

Penelitian ini dilakukan di Fakultas Ekonomi dan Bisnis Universitas Ahmad Dahlan Yogyakarta. Peneliti menggunakan kuesioner tertutup, di mana pernyataan disajikan dalam bentuk terstruktur sehingga responden diminta untuk memilih salah satu jawaban yang sesuai dengan karakteristik dirinya. Jumlah responden yang dianalisis dalam penelitian ini berjumlah 70 orang. Dari hasil 100 orang tersebut dapat diketahui gambaran responden yang diteliti yaitu:

1. Karakteristik Berdasarkan Program Studi

Deskripsi karakteristik mahasiswi Muslim di Fakultas Ekonomi dan Bisnis Universitas Ahmad Dahan berdasarkan program studi disajikan pada tabel dibawah ini:

Tabel 1. Karakteristik Responden Berdasarkan Program Studi

\begin{tabular}{|c|c|c|}
\hline Program Studi & Frekuensi & Prosentase \\
\hline Manajemen & 24 & $34,4 \%$ \\
\hline Akuntansi & 23 & $32,8 \%$ \\
\hline Ekonomi Pembangunan & 23 & $32,8 \%$ \\
\hline Jumlah Responden & $\mathbf{7 0}$ & $\mathbf{1 0 0}$
\end{tabular}

2. Karakteristik Berdasarkan Semester

Deskripsi karakteristik mahasiswi muslim di Fakultas Ekonomi dan Bisnis Universitas Ahmad Dahan berdasarkan semester disajikan pada tabel dibawah ini:

Tabel 2. Karakteristik Responden Berdasarkan Semester

\begin{tabular}{|c|c|c|}
\hline Semester & Frekuensi & Prosentase \\
\hline Semester II & 28 & $40 \%$ \\
\hline Semester IV & 13 & $18,5 \%$ \\
\hline Semester VI & 20 & $28,6 \%$ \\
\hline Semester VIII & 9 & $12,9 \%$ \\
\hline Jumlah & $\mathbf{7 0}$ & $\mathbf{1 0 0}$ \\
\hline
\end{tabular}

3. Karakteristik Berdasarkan Usia

Deskripsi karakteristik mahasiswi muslim di Fakultas Ekonomi dan Bisnis Universitas Ahmad Dahan berdasarkan semester disajikan pada tabel dibawah ini:

Tabel 3. Karakteristik Responden Berdasarkan Usia

\begin{tabular}{|c|c|c|}
\hline Usia & Frekuensi & Prosentase \\
\hline $17-20$ Tahun & 51 & $72,9 \%$ \\
\hline $21-24$ Tahun & 19 & $27,1 \%$ \\
\hline Jumlah & $\mathbf{7 0}$ & $\mathbf{1 0 0} \%$ \\
\hline
\end{tabular}

Sesuai dengan permasalahan yang telah dikemukakan, maka teknik analisis data yang digunakan dalam penelitian ini adalah analisis data kuantitatif. Dalam penelitian ini menggunakan teknik analisis linier berganda. Dimana sebelum data di analisis lebih lanjut, maka terlebih dahulu data yang diperoleh tersebut dilakukan uji validitas dan uji reliabilitas sehingga hasil kesimpulan yang diperoleh dalam penelitian ini dapat dinyatakan valid dan tidak menimbulkan nilai yang tidak bias. 


\subsection{Hasil Analisis \\ Uji Reliabilitas}

Dalam pengujian ini dilakukan dengan uji statistik Cronbach Alpha $(\alpha)$. Menurut Adhilla (2013) suatu konstruk atau variabel dikatakan reliabel jika memberikan nilan Cronbach Alpha $(\alpha)>0,60$. Adapun hasil uji reliabilitas pada pengujian ini untuk masing-masing variabel adalah sebagai berikut:

Tabel 4. Hasil Pengujian Reliabilitas

\begin{tabular}{|l|c|c|c|}
\hline \multicolumn{1}{|c|}{ Variabel } & Nilai cronbach's alpha & $\begin{array}{c}\text { Alpha (Rule of } \\
\text { Thumb) }\end{array}$ & Keterangan \\
\hline Religiusitas $\left(\mathrm{X}_{1}\right)$ & 0,729 & 0,60 & Reliabel \\
\hline Sikap $\left(\mathrm{X}_{2}\right)$ & 0,944 & 0,60 & Reliabel \\
\hline Norma Subjektif $\left(\mathrm{X}_{3}\right)$ & 0,891 & 0,60 & Reliabel \\
\hline Kontrol Perilaku $\left(\mathrm{X}_{4}\right)$ & 0,791 & 0,60 & Reliabel \\
\hline Niat $(\mathrm{Y})$ & 0,935 & 0,60 & Reliabel
\end{tabular}

Berdasarkan hasil uji reliabilitas diatas, dapat diketahui nilai koefisian cronbach alpha $(\alpha)$ pada masingmasing variabel $>0,60$ maka dapat disimpulkan bahwa semua pernyataan dalam penelitian ini adalah reliabel dan dapat digunakan untuk penelitian berikutnya.

\section{Analisis Regresi Linier Berganda}

Tabel 5. Hasil Pengolahan Data Analisis Regresi Berganda

\begin{tabular}{|c|c|c|}
\hline Model & t Test & Sig. \\
\hline (Constant) & $-0,132$ & 0,895 \\
\hline Religiusitas & 1,180 & 0,242 \\
\hline Sikap & $-0,664$ & 0,509 \\
\hline Norma Subjektif & 1,162 & 0,250 \\
\hline Kontrol Perilaku & 6,931 & 0,000 \\
\hline
\end{tabular}

Berdasarkan hasil dari pengolahan data maka dapat diketahui persamaan linier berganda yaitu:

$$
Y=-0,132+1,180 X_{1}-0,664 X_{2}+1,162 X_{3}+6,931 X_{4}+e
$$

Dari persamaan garis linier regresi berganda diatas, dapat diartikan bahwa:

$\mathrm{Y}=$ variabel yang nilainya akan diprediksi oleh variabel independen. Dalam penelitian ini yang menjadi variabel dependen adalah niat membeli produk kosmetik halal, yang nilainya diprediksi oleh variabel reigiusitas, sikap, norma subjektif dan kontrol perilaku.

$\mathrm{a}=-0,132$ merupakan nilai konstanta, dengan demikian nilai konstanta ini menunjukkan besarnya nilai variabel niat membeli produk kosmetik halal jika variabel independen sama dengan nol.

$\mathrm{X}_{1}=1,180$ merupakan koefisien variabel religiusitas $\left(\mathrm{X}_{1}\right)$ yang mempengaruhi niat membeli produk kosmetik halal $(\mathrm{Y})$. Koefisien regresi $\left(\mathrm{X}_{1}\right)$ sebesar 1,180 dengan tanda positif. Berdasarkan hasil tersebut, maka dapat disimpulkan bahwa apabila religiusitas $\left(\mathrm{X}_{1}\right)$ berubah atau naik satu-satuan maka niat membeli produk kosmetik halal akan naik sebesar 1,180 dengan asumsi variabel independen lainnya mempunyai nilai sama dengan nol.

$\mathrm{X}_{2}=-0,664$ merupakan koefisien variabel sikap $\left(\mathrm{X}_{2}\right)$ yang mempengaruhi niat membeli produk kosmetik halal (Y). Koefisien regresi $\left(\mathrm{X}_{2}\right)$ sebesar -0,664 dengan tanda negatif. Berdasarkan hasil tersebut, maka dapat disimpulkan bahwa apabila sikap $\left(\mathrm{X}_{2}\right)$ berubah atau naik satu-satuan, maka niat membeli produk kosmetik halal akan naik sebesar -0,664 dengan asumsi variabel independen lainnya mempunyai nilai sama dengan nol.

$\mathrm{X}_{3}=1,162$ merupakan koefisien variabel norma subjektif $\left(\mathrm{X}_{3}\right)$ yang mempengaruhi niat membeli produk kosmetik $(\mathrm{Y})$. koefisien regresi $\left(\mathrm{X}_{3}\right)$ sebesar 1,162 dengan tanda positif. Berdasarkan hasil tersebut, maka dapat disimpulkan bahwa apabila norma subjektif $\left(\mathrm{X}_{3}\right)$ berubah atau naik satu-satuan, maka niat membeli produk kosmetik halal akan naik sebesar 1,162 dengan asumsi variabel independen lainnya mempunyai nilai sama dengan nol.

$\mathrm{X}_{4}=6,931$ merupakan koefisien variabel kontrol perilaku $\left(\mathrm{X}_{4}\right)$ yang mempengaruhi niat membeli produk kosmetik halal $(\mathrm{Y})$. koefisien regresi $\left(\mathrm{X}_{4}\right)$ sebesar 6,931 dengan tanda positif. Berdasarkan hasil tersebut maka dapat disimpulkan bahwa apabila kontrol perilaku $\left(\mathrm{X}_{4}\right)$ berubah atau naik satu-satuan maka niat membeli produk kosmetik halal akan naik sebesar 6,931 dengan asumsi variabel independen lainnya mempunyai nilai sama dengan nol.

Uji Signifikasi Secara Parsial (Uji t)

Tabel 6. Hasil Pengujian data Uji $t$

\begin{tabular}{|c|c|c|c|}
\hline Model & $\mathbf{t}$ Test & Sig. & Keterangan \\
\hline Religiusitas $\left(\mathrm{X}_{1}\right)$ & $-0,132$ & 0,242 & Tidak berpengaruh signifikan \\
\hline Sikap $\left(\mathrm{X}_{2}\right)$ & 1,180 & 0,509 & Tidak berpengaruh signifikan \\
\hline Norma Subjektif $\left(\mathrm{X}_{3}\right)$ & $-0,664$ & 0,250 & Tidak berpengaruh signifikan \\
\hline Kontrol Perilaku $\left(\mathrm{X}_{4}\right)$ & 1,162 & 0,000 & Berpengaruh signifikan
\end{tabular}

Berdasarkan hasil olah data diatas dapat disimpulkan sebagai berikut:

a. Variabel Religiusitas (X1)

$\mathrm{H}_{0}$ : Tidak ada pengaruh signifikan antara religiusitas terhadap niat membeli produk kosmetik halal.

$\mathrm{H}_{\mathrm{a}}$ : Ada pengaruh signifikan antara religiusitas terhadap niat membeli produk kosmetik halal.

Untuk variabel religiusitas $\left(\mathrm{X}_{1}\right)$, dari hasil olah data menggunakan SPSS 20 nilai sign $>$ alpha $(0,242>0,05)$, sehingga religiusitas $\left(\mathrm{X}_{1}\right)$ tidak berpengaruh signifikan terhadap niat membeli (Y). Maka dapat disimpulkan $\mathrm{H}_{0}$ diterima dan $\mathrm{H}_{\mathrm{a}}$ ditolak yaitu tidak ada pengaruh positif antara religiusitas terhadap niat membeli produk kosmetik halal.

b. Variabel Sikap (X2)

$\mathrm{H}_{0}$ : Tidak ada pengaruh signifikan antara sikap terhadap niat membeli produk kosmetik halal. 
$\mathrm{H}_{\mathrm{a}}$ : Ada pengaruh signifikan antara sikap terhadap niat membeli produk kosmetik halal.

Untuk variabel sikap $\left(\mathrm{X}_{2}\right)$, dari hasil olah data menggunakan SPSS 20 nilai sign $>$ alpha $(0,509>0,05)$, sehingga sikap $\left(\mathrm{X}_{2}\right)$ tidak berpengaruh signifikan terhadap niat membeli (Y). Maka dapat disimpulan $\mathrm{H}_{0}$ diterima dan $\mathrm{H}_{\mathrm{a}}$ ditolak yaitu tidak ada pengaruh positif antara sikap terhadap niat membeli produk kosmetik halal.

\section{c. Variabel Norma Subjektif (X3)}

$\mathrm{H}_{0}$ : Tidak ada pengaruh signifikan antara norma subjektif terhadap niat membeli produk kosmetik halal.

$\mathrm{H}_{\mathrm{a}}$ : Ada pengaruh signifikan antara norma subjektif terhadap niat membeli produk kosmetik halal.

Untuk variabel norma subjektif $\left(\mathrm{X}_{3}\right)$, dari hasil olah data menggunakan SPSS 20 nilai sign $>$ alpha $(0,250>$ $0,05)$, sehingga norma subjektif $\left(\mathrm{X}_{3}\right)$ tidak berpengaruh signifikan terhadap niat membeli (Y). Maka dapat disimpulan $\mathrm{H}_{0}$ diterima dan $\mathrm{H}_{\mathrm{a}}$ ditolak yaitu tidak ada pengaruh positif antara norma subjektif terhadap niat membeli produk kosmetik halal.

\section{d. Variabel Kontrol Perilaku (X4)}

$\mathrm{H}_{0}$ : Tidak ada pengaruh signifikan antara kontrol perilaku terhadap niat membeli produk kosmetik halal.

$\mathrm{H}_{\mathrm{a}}$ : Ada pengaruh signifikan antara kontrol perilaku terhadap niat membeli produk kosmetik halal.

Untuk variabel kontrol perilaku $\left(\mathrm{X}_{4}\right)$, dari hasil olah data menggunakan SPSS 20 nilai sign $<$ alpha $(0,000<$ 0,05), sehingga kontrol perilaku $\left(\mathrm{X}_{4}\right)$ berpengaruh signifikan terhadap niat membeli (Y). Maka dapat disimpulan $\mathrm{H}_{0}$ ditolak dan $\mathrm{H}_{\mathrm{a}}$ diterima yaitu ada pengaruh positif antara kontrol perilaku terhadap niat membeli produk kosmetik halal.

\section{Uji Signifikansi Secara Simultan (Uji F)}

Tabel 7. Hasil olah data Uji F

\begin{tabular}{|ll|c|c|}
\hline Model & F & Sig. \\
\hline 1 & $\begin{array}{l}\text { Regression } \\
\text { Residual } \\
\text { Total }\end{array}$ & 28,135 & $.000^{\mathrm{b}}$ \\
\hline
\end{tabular}

Berdasarkan dari hasil olah data dengan menggunakan SPSS 20, nilai sign $<$ alpha $(0,000<0,05)$. Dengan demikian dapat disimpulkan bahwa Ada pengaruh signifikan antara religiusitas, sikap, norma subjektif, dan kontrol perilaku terhadap niat membeli produk kosmetik halal.

\section{Diskusi}

Berdasarkan dari hasil uji t, dari keempat yang mempengaruhi niat membeli yaitu religiusitas, sikap, norma subjektif, dan kontrol perilaku sebagai berikut:

1. Pengaruh antara variabel religiusitas terhadap niat membeli produk kosmetik halal tidak signifikan. Hal ini dikarenakan nilai sign $>$ alpha $(0,242>0,05)$, sehingga religiusitas $\left(\mathrm{X}_{1}\right)$ tidak berpengaruh posisitf terhadap niat membeli (Y). Maka dapat diambil kesimpulan $\mathrm{H}_{01}$ diterima dan $\mathrm{H}_{\mathrm{a} 1}$ ditolak yaitu tidak ada pengaruh positif antara religiusitas terhadap niat membeli produk kosmetik halal. Dengan demikian religiusitas tidak mempengaruhi niat konsumen untuk membeli produk kosmetik yang halal. Karena pada dasarnya perempuan ingin selalu terlihat cantik, dan fenomena yang ada pada masa sekarang ini masih banyak wanita yang berhias belum sesuai dengan syari'at islam, karena kaum perempuan sekarang lebih banyak tertarik kepada produk kosmetik yang instant tanpa mengetahui halal atau pun haramnya demi terlihat lebih cantik. Dan dari itu tingkat religiusitas perempuan di Fakultas Ekonomi dan Bisnis Universitas Ahmad Dahlan masih sangat rendah.

2. Pengaruh antara variabel sikap terhadap niat membeli produk kosmetik halal tidak signifikan. Hal ini dikarenakan nilai sign $>$ alpha $(0,509>0,05)$, sehingga sikap $\left(\mathrm{X}_{2}\right)$ tidak berpengaruh positif terhadap niat membeli (Y). Maka dapat diambil kesimpulan $\mathrm{H}_{02}$ diterima dan $\mathrm{H}_{\mathrm{a} 2}$ ditolak yaitu tidak ada pengaruh positif tempat terhadap niat membeli produk kosmetik halal. Dengan demikian sikap tidak mempengaruhi niat konsumen untuk membeli produk kosmetik halal. Karena kebanyakan perempuan sekarang lebih mengutamakan penampilan dan lebih cenderung menggunakan produk-produk yang dirasa membuat diri mereka lebih terlihat cantik, tanpa memperhatikan tingkat kehalalan dan keharaman produk tersebut. Sehingga kecenderungan mereka tehadap produk yang biasa mereka gunakan lebih besar, dari pada harus memperhatikan produk tersebut halal atau haram. Dan dari itu sikap yang dimiliki perempuan di Fakultas Ekonomi dan Bisnis Universitas Ahmad Dahlan dalam pemilihan produk halal masih sangat rendah.

3. Pengaruh antara variabel norma subjektif terhadap niat membeli produk kosmetik halal tidak signifikan. Hal ini dikarenakan nilai sign $>$ alpha $(0,250>0,05)$, sehingga norma subjektif $\left(\mathrm{X}_{3}\right)$ tidak berpengaruh positif terhadap niat membeli (Y). maka dapat diambil kesimpulan $\mathrm{H}_{03}$ diterima dan $\mathrm{H}_{\mathrm{a}}$ ditolak yaitu tidak ada pengaruh positif antara norma subjektif terhadap niat membeli produk kosmetik halal. Dengan demikian norma subjektif tidak mempengaruhi niat konsumen untuk membeli produk kosmetik halal. Kebanyakan perempuan sekarang dalam menggunakan produk berdasarkan kecocokan dalam pemillihan produk tersebut saat dipakai, sehingga tidak begitu mengikuti trend 
merek yang sedang banyak disukai oleh kebanyakan orang lainnya, akan tetapi lebih pada kecocokan pada penggunaan produk tersebut. Karena banyak produk yang sedang terkenal akan tetapi tidak cocok dalam penggunaan. Dan dari itu norma subjektif yang mempengaruhi perempuan di Fakultas Ekonomi dan Bisnis Universitas Ahmad Dahlan dalam pemilihan produk halal masih sangat rendah.

4. Pengaruh antara variabel kontrol perilaku terhadap niat membeli produk kosmetik halal signifikan. Hal ini dikarenakan nilai sign $<$ alpha $(0,000<0,05)$, sehingga kontrol perilaku $\left(\mathrm{X}_{4}\right)$ berpengaruh positif terhadap niat membeli (Y). maka dapat diambil kesimpulan $\mathrm{H}_{04}$ ditolak dan $\mathrm{H}_{\mathrm{a}}$ diterima, yaitu ada pengaruh positif antara kontrol perilaku terhadap niat membeli produk kosmetik halal. Dengan demikian kontrol perilaku mempengaruhi niat konsumen untuk membeli produk kosmetik halal. Karena banyak perempuan masih mempercayai sumber-sumber yang jelas mengenai produk-produk yang baik untuk digunakan atau tidak, sehingga membuat mereka lebih berhati-hati dalam membeli dan menggunakan produk kosmetik tersebut. Sehingga tingkat kontrol perilaku perempuan di Fakultas Ekonomi dan Bisnis Universitas Ahmad Dahlan tinggi.

Dan dari hasil uji $\mathrm{F}$ empat variabel independen berpengaruh signifikan terhadap variabel dependen. Hal ini dikarenakan nilai sign $<$ alpha $(0,000<0,05)$, sehingga $\mathrm{H}_{\mathrm{a}}$ diterima dan $\mathrm{H}_{0}$ ditolak. Dengan demikian dapat ditarik kesimpulan bahwa ada pengaruh positif antara religiusitas, sikap, norma subjektif dan kontrol perilaku terhadap niat membeli produk kosmetik halal.

\section{Kesimpulan}

Berdasarkan analisis hasil penelitian dan pembahasan yang telah dilakukan pada bab sebelumnya, maka dapat ditarik kesimpulan sebagai berikut:

1. Variabel religiusitas tidak berpengaruh signifikan terhadap niat membeli produk kosmetik halal di Fakultas Ekonomi dan Bisnis Universitas Ahmad Dahlan dengan nilai signifikan sebesar 0.531. Hal ini menunjukkan bahwa religiusitas tidak mempengaruhi niat dalam membeli produk kosmetik halal mahasiswi di Fakultas Ekonomi dan Bisnis Universitas Ahmad Dahlan.

2. Variabel sikap tidak berpengaruh signifikan terhadap niat membeli produk kosmetik halal di Fakultas Ekonomi dan Bisnis Universitas Ahmad Dahlan dengan nilai signifikan sebesar 0.531. Hal ini menunjukkan bahwa sikap tidak mempengaruhi niat dalam membeli produk kosmetik halal mahasiswi di Fakultas Ekonomi dan Bisnis Universitas Ahmad Dahlan.

3. Variabel norma subjektif tidak berpengaruh signifikan terhadap niat membeli produk kosmetik halal di Fakultas Ekonomi dan Bisnis Universitas Ahmad Dahlan dengan nilai signifikan sebesar 0.240. Hal ini menunjukkan bahwa norma subjektif tidak mempengaruhi niat dalam membeli produk kosmetik halal mahasiswi di Fakultas Ekonomi dan Bisnis Universitas Ahmad Dahlan.

4. Variabel kontrol perilaku berpengaruh signifikan terhadap niat membeli produk kosmetik halal di Fakultas Ekonomi dan Bisnis Universitas Ahmad Dahlan dengan nilai signifikan sebesar 0.000. Hal ini menunjukkan bahwa kontrol perilaku mempengaruhi niat dalam membeli produk kosmetik halal mahasiswi di Fakultas Ekonomi dan Bisnis Universitas Ahmad Dahlan.

Dari hasil olah data uji F, keempat variabel independen berpengaruh signifikan terhadap variabel dependen. Sehingga dapat ditarik kesimpulan bahwa variabel religiusitas, sikap, norma subjektif dan kontrol perilaku secara simultan atau bersama-sama mempunyai pengaruh terhadap niat membeli produk kosmetik halal di Fakultas Ekonomi dan Bisnis Universitas Ahmad Dahlan.

\section{Daftar Pustaka}

Adhilla Fitroh, Dyah Fitriani. Dan Deny Ismanto. 2013. Modul Praktikum Statistik 2. Yogyakarta. Fakultas Ekonomi Universitas Ahmad Dahlan. 19-20.

Ajzen, Icek. 1991. The Theory of Planned Behavior. Organizational Behavior and Human Decision Processes vol 50, pp 179-211.

Ajzen. Icek. 2005. Attitudes, Personality, and Behavior. Open University Press

Alam, Syed Shah, et.al. 2012. Is Religiosity an Important Factor In Influencing The Intention to Undertake Islamic Home Financing in Klang Valley. World Applied Sciences Journal 19 (7) : 1030-1041.

Arikunto, Suharsimi. 2013. Prosedur Penelitian Suatu Pendekatan Praktik. Jakarta : Rineka Cipta

Aziz, Nooren Noor Abd. Wahab, Eta. Understanding of Halal Cosmetics Product:TPB Model.

Burhanuddin. 2011. Pemikiran Hukum Perlindungan Konsumen dan Sertifikat Halal. Malang : UIN Maliki Press.

Dominanto, Nedi Nugrah. 2008. Perbedaan Sikap terhadap Iklan, Merek dan Niat Beli Konsumen pada Iklan dengan Fear Appeal Tinggi dan Rendah pada Partisipan Wanita. Jurnal Ekonomi dan Bisnis 2 (2), h: 67-75.

Fishbein, Martin dan Icek Ajzen. 1975. Belief, attitude, intention and behavior an introduction to theory and research. London: Addiso Wesley Publishing Company.

Ghozali, Imam. (2002). Pengaruh Religiositas terhadap Komitmen Organisasi, Keterlibatan Kerja, Kepuasan.

Kerja dan Produktivitas. Jurnal Bisnis Strategi. Semarang: Universitas Diponegoro Semarang.

Hair, J.F.Jr. et. al. 1998. Multivariate Data Analysis, (5 Edition). Upper Saddle River, NJ : Prentice Hall.

Kardes, R. Frank et.al. 2008. Cunsomer Behavior. USA : South-Western Cengage Learning. 
Kotler, Philip. 1995. Manajemen Pemasaran. Jakarta : Penerbit Salemba Empat.

Kotler, Philip., dan Kevin Lane Keller. 2008. Manajemen Pemasaran. Jakarta: Indeks.

Kotler, Philip., dan Kevin Lane Keller. 2009. Manajemen Pemasaran. Jakarta: Indeks.

Marliani, Rosleny. 2013. Hubungan Antara Religiusitas dengan Orientasi Masa Depan Bidang Pekerjaan pada Mahasiswa Tingkat Akhir. Jurnal Psikologi, volume 9, nomor 2, Desember.

Minkler, Lanse., dan Metin Cosgel. 2004. Religious Identity and Comsumption, University of Connecticut.

Naini, Rohmatus. 2015. Wellnes Ditinjau Dari Religiusitas Mahasiswa Universitas Negeri Yogyakarta. Jurnal Bimbingan dan Konseling, Edisi 4, Tahun ke 4.

Nasrullah, Muhammad. 2015. Islamic Branding, Religiusitas dan Keputusan Konsumen Tehadap Produk. Jurnal Hukum Islam (JHI), volume 13, nomor 2, Desember 2015 : 79-87.

Nawari. 2010. Analisis Regresi dengan MS Excel 2007 dan SPSS 17. Jakarta: PT. Elek Media Komputindo.

Purwanto, M. Ngalim 2007. Psikologi Pendidikan. Cetakan Pertama. Remaja. Rosdakarya. Bandung.

Schiffman, Leon, L. Lazar Kanuk. 2008. Perilaku Konsumen. Jakarta: PT. INDEKS.

Schiffman, Leon G, and Leslie Lazar Kanuk. 2000. Consumer Behavior 7e, Int Edition. New Jersey: Prenhallindo.

Sudrajat, Ajat, dkk. (2009). Din Al Islam: Pendidikan Agama Islam di Perguruan Tinggi Umum. Yogyakarta: UNY Press.

Sugiyono. 2015. Metode Penelitian Pendidikan, Pendekatan Kuantitatif, Kualitatif, dan $R \& D$. Bandung: Alfabeta.

Peraturan Kementrian Kesehatan No. 445 Tahun 1998.

http://id.wikipedia.org/wiki/LPPOM_MUI 